\title{
Contents for Volume 14
}

\section{TERRY F. BUSS}

Unemployment Rates and Their Implications for Human Resource Planning

B.M. BALK and H.M.P. KERSTEN

On the Precision of Consumer Price Indices Caused by the Sampling

Variability of Budget Surveys

STANLEY K. SMITH

Using Medicare Data for Short-Run Projections of the Elderly Population

LEROY BROOKS and DALE BUCKMASTER

The Impact of Inflation on the Monetary Stocks of the Firm

BRENT R. MOULTON

An Analysis of Female Work Experience Data Derived from Social Security Records

J. STEVEN LANDEFELD and EUGENE P. SESKIN

A Comparison of Anticipatory Surveys and Econometric Models in Forecasting U.S. Business Investment

DALE HEIEN and CAROLE NUCKTON

A Note on the Savings Rate

LEO GREBLER

Household Saving in an Era of Financial Turmoil, 1975-1984

JOHN M. KENNEDY, GORDON F. DeJONG, and DANIEL T. LICHTER

Updating Local Area Population Projections with Current Migration

Estimates

HARRIET ORCUTT DULEEP

Incorporating Longitudinal Aspects into Mortality Research Using Social

Security Administrative Record Data

EUN SUL LEE, RONALD N. FORTHOFER, CHARLES E. HOLZER, III, and CARL A. TAUBE

Complex Survey Data Analysis: Estimation of Standard Errors Using

Pseudostrata

KEITH A. SHRIVER

A Statistical Test of the Stability Assumption Inherent in Empirical

Estimates of Economic Depreciation 
STEVEN G. LANNING

Missing Observations: A Simultaneous Approach versus Interpolation by Related Series

JOHN H. HERBERT

Data Analysis, Specification, and Estimation of an Aggregate Relationship for Sales of Natural Gas per Customer

JOHN C. WEICHER

Simple Measures of Inadequate Housing

MARC L. BERK, CONSTANCE M. HORGAN, and SAMUEL M. MEYERS

The Reporting of Stimatizing Health Conditions: A Comparison of Proxy and Self-Reporting

FRANK R. LICHTENBERG

The Duration and Intensity of Investment in Independent Research and Development Projects

THOMAS M. HOLLOWAY

Simple Methods to Measure the Automatic Responsiveness of the Federal Budget to Inflation

KATHERINE SWARTZ

Interpreting the Estimates From Four National Surveys of the Number of People Without Health Insurance

CARL A. TAUBE, WILLIAM E. SCHLENGER, AGNES RUPP, and ROY W.

WHITMORE

Validity of Medicaid Household Respondent Reporting of Ambulatory Visits for Mental Disorders

L. WORRALL

The Analysis and Management of Urban Change: The Role of Local Information Systems

W.F. MAUNDER and M.C. FLEMING

Reviews of United Kingdom Statistical Sources

D. SAPSFORD

A New Contribution in the Statistical Debate Over Trends in the Net Barter Terms of Trade Between Primary Commodities and Manufactures

KEITH A. SHRIVER

The Valuation of Used Capital Assets During Time Periods Exhibiting Alternative Degrees of Demand for Industrial Machinery and Equipment 
KEVIN F. McCROHAN

The Revenue Loss Due to Undocumented Alien Earnings:

Estimates for 1980

SANG V. NGUYEN and STEPHEN H. ANDREWS

Measuring Service Prices of U.S. Manufacturing Capital Input, Inventories, and Financial Working Capital, 1947-1981

MARISOL PEREZ-CHOPRA and RICHARD M. GRIMES

Inflation and Health Care Costs in Metropolitan Areas

A. REISMAN, P.H. RITCHKEN, BRUCE POLLACK-JOHNSON, B.V. DEAN, E.S ESCUETA, and GANG LI

On the Voids in U.S. National Education Statistics

STEVEN B. COHEN

Data Collection Organization Effect in the National Medical Care Utilization and Expenditure Study

JANICE SHACK-MARQUEZ

Effects of Repeated Interviewing on Estimation of Labor Force Status 